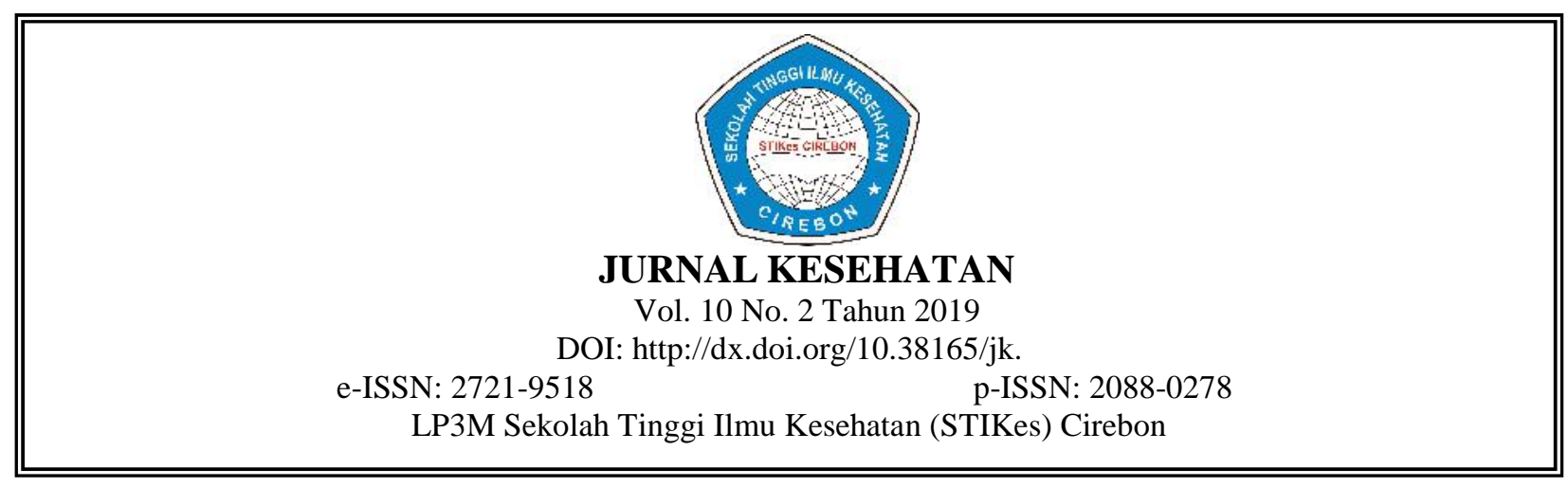

\title{
FAKTOR-FAKTOR YANG BERHUBUNGAN DENGAN TERJADINYA STRES KERJA PADA PEKERJA WANITA
}

\author{
Muslimin* \\ Program Studi Kesehatan Masyarakat Sekolah Tinggi Ilmu Kesehatan Cirebon \\ mistermuslimin@gmail.com \\ I Gede Eka** \\ Program Studi Kesehatan Masyarakat Sekolah Tinggi Ilmu Kesehatan Cirebon
}

\begin{abstract}
Abstrak
Semakin banyak terbukanya peluang kerja yang saat ini terjadi, tidak menutup kemungkinan masuknya wanita ke dalam dunia kerja. Dari meningkatkanya wanita yang terlibat dalam dunia kerja sebagai salah satu prestasi bagi wanita tersebut, ternyata wanita bekerja dikabarkan memiliki ancaman cukup serius untuk terkena stres kerja. Stres kerja memiliki beberapa dampak negatif, diantaranya dapat menyebabkan gangguan kesehatan dan menurunkan produktivitas kerja. Penelitian ini bertujuan untuk mengetahui faktor-faktor yang berhubungan dengan stres kerja pada pekerja wanita di PT. Shoetown Majalengka Provinsi Jawa Barat Tahun 2019. Penelitian ini merupakan penelitian kuantitatif dengan desain penelitian cross sectional. Populasi penelitian ini adalah wanita bekerja yang bekerja di PT Shoetown Majalengka periode bulan Juni 2019 sebanyak 1785 orang dengan sampel berjumlah 95 responden. Data yang digunakan dalam penelitian ini adalah data sekunder dari perusahaan terkait dan data primer yang diperoleh melalui wawancara kepada responden. Pengumpulan data penelitian menggunakan kuisioner dan dianalisa menggunakan uji chi square. Dari hasil penelitian didapatkan bahwa ada hubungan yang bermakna antara beban kerja dengan kejadian stres kerja ( $p$ value 0,040$)$, ada hubungan yang bermakna antara kejenuhan kerja dengan kejadian stres kerja ( $p$ value 0,035$)$, ada hubungan yang bermakna antara lingkungan kerja dengan kejadian stres kerja ( $\mathrm{p}$ value 0,046$)$.
\end{abstract}

Kata Kunci: Stres, Beban, Kejenuhan, Lingkungan, Pekerja

\begin{abstract}
The more open job opportunities that currently occur, do not rule out the entry of women into the world of work. From increasing the number of women involved in the workforce as an achievement for these women, it turns out that working women are reported to have a serious enough threat to be exposed to work stress. Job stress has several negative impacts, including can cause health problems and reduce work productivity. This study aims to determine the factors associated with work stress on female workers at PT. Shoetown Majalengka, West Java Province in 2019. This research is a quantitative study with cross sectional research design. The population of this study was working women who worked at PT Shoetown Majalengka for the period of June 2019 with 1785 people with a sample of 95 respondents. The data used in this study are secondary data from related companies and primary data obtained through interviews with respondents. Research data collection using questionnaires and analyzed using chi square test.From the results of the study found that there is a significant relationship between workload and work stress events ( $p$ value 0.040), there is a significant relationship between work burnout and work stress events ( $p$ value 0.035), there is a significant relationship between work environment and work stress events ( $p$ value 0.046)
\end{abstract}

Keywords: Stress, Workload, Saturation, Environment, Workers 


\section{PENDAHULUAN}

Stres kerja merupakan masalah kesehatan yang umum terjadi dan sering dikeluhkan oleh pekerja di berbagai Negara. Di Amerika, stres kerja merupakan masalah yang umum terjadi dan merugikan bagi pekerja. Menurut data WHO tahun 2014, di banyak Negara sekitar 8\% penyakit yang ditimbulkan akibat pekerjaan adalah depresi. Dalam sebuah survei yang dilakukan oleh Princeton Survey Research Associates, diketahui bahwa tiga dari empat orang di Amerika mengatakan bahwa pekerja pada saat ini memiliki tingkat stres kerja yang lebih tinggi dibandingkan dengan generasi beberapa tahun sebelumnya. Sementara hasil penelitian Labour Force Survey tahun 2014, menemukan bahwa terdapat 440.000 kasus stress akibat kerjadi Inggris dengan angka kejadian sebanyak1.380 kasus per100.000 pekerja yang mengalami stress akibat kerja. Sementara Komisi Kesehatan Mental Kanada (Mental Health Commission of Canada) tahun 2016, mencatat bahwa setidaknya terdapat 1 dari 5 orang Kanada yang mengalami masalah kesehatan psikologis pada tahun tertentu serta terdapat $47 \%$ pekerja Kanada menganggap bahwa pekerjaan mereka merupakan bagian yang paling menyebabkan stres dalam kehidupan sehari-hari.?

Stres kerja tidak terjadi begitu saja, faktor penyebab stres kerja di pekerjaan dikelompokkan menjadi faktor-faktor intrinsik dalam pekerjaan, peran individu dalam organisasi, pengembangan karir, hubungan dalam pekerjaan, dan struktur dan iklim organisasi. Kemudian penyebab stres kerja dikelompokkan berdasarkan empat area atau lingkungan yakni lingkungan kerja, rumah, sosial, dan individu. ${ }^{5}$

Faktor stres kerja bersumber pada pekerjaan, karakteristik indvidu, dan luar organisasi. ${ }^{6}$ Faktor penyebab stres kerja dikelompokkan menjadi tiga sumber yaitu faktor yang bersumber dari lingkungan, organisasi, dan individu dimana pengelompokan besar ini serupa dengan pengelompokan penyebab stres kerja oleh National Safety Council namun tidak sama dalam penggolongan faktor-faktor yang lebih rincinya. ${ }^{7}$

Lebih rinci faktor penyebab stres kerja menurut National Safety Council tersebut yakni berupa kurangnya otonomi, beban kerja, relokasi pekerjaan, kurangnya pelatihan, perkembangan karir, hubungan yang buruk dengan atasan, perkembangan teknologi, bertambahnya tanggung jawab tanpa pertambahan gaji, dan pekerja yang dikorbankan (faktor organisasional), pertentangan antara karir dan tanggung jawab keluarga, ketidakpastian ekonomi, kurangnya penghargaan kerja, kejenuhan kerja, perawatan anak, dan konflik dengan rekan kerja (faktor individu), buruknya kondisi lingkungan kerja, pelecehan seksual, kekerasan di tempat kerja, kemacetan saat berangkat dan pulang kerja, dan diskriminasi ras (factor lingkungan). ${ }^{8}$

Terkait faktor-faktor stres kerja tersebut, terdapat beberapa penelitian yang telah dilakukan sebelumnya, diantaranya yakni Saragih dalam penelitiannya mengenai kurangnya otonomi kerja terhadap 70 responden, menyebutkan bahwa dari $47,1 \%$ responden yang tidak memiliki otonomi dalam melaksanakan tugasnya, terdapat $54,5 \%$ mengalami stres kerja. ${ }^{9}$ Selanjutnya dalam hasil penelitian terhadap hubungan pekerja dengan atasan, Nugrahani menyebutkan bahwa dari buruknya hubungan responden dengan atasan atau supervisor terdapat 58,8\% responden mengalami stres kerja sedang. ${ }^{10}$ Kemudian Airmayanti, dalam hasil penelitiannya terhadap 108 sampel disebutkan bahwa dari 19 responden yang menyatakan beban kerja berat terdapat 73,3\% mengalami stres kerja berat dan dari beban kerja sedang sebesar 57 responden terdapat 59,6\% mengalami stres ringan. ${ }^{11}$

Semakin banyak terbukanya peluang kerja yang saat ini terjadi, tidak menutup kemungkinan masuknya kaum wanita ke dalam dunia kerja. Dari hasil Susenas BPS tahun 2010 disebutkan bahwa keikutsertaan wanita dalam dunia kerja adalah sebesar 51,76\% dan pria sebesar 48,24\% dari penduduk usia produktif (15-64 tahun). ${ }^{12}$

Wanita pekerja secara biologis berbeda dengan pekerja pria, terutama dalam hal fungsi reproduksi, seperti haid, hamil, melahirkan, dan menyusui. Kondisi seperti ini menyebabkan wanita tidak dapat melakukan pekerjaannya secara maksimal, terutama untuk pekerjaan yang membutuhkan aktivitas fisik berlebih. Pekerja wanita memiliki kecenderungan lebih mudah mengalami stres dibandingkan pria. ${ }^{13}$ 
Wanita yang bekerja memiliki banyak tuntutan berupa tumpukan pekerjaan yang seolah tak ada habisnya, terkadang adanya suasana kerjasama yang kurang menyenangkan dari rekan kerja, tingginya tuntutan atasan dan berbagai kondisi lainnya sudah menjadi makanan sehari-hari. Berbagai tuntutan kerja di atas tidak bisa dihindari oleh wanita yang memutuskan tetap bekerja.

Para wanita yang bekerja mengalami stres lebih tinggi dibandingkan dengan pria, dimana salah satu faktor tersebut karena wanita yang bekerja menghadapi konflik peran sebagai wanita karir sekaligus ibu rumah tangga. Kemudian pekerja wanita mengalami level stres yang lebih tinggi dibandingkan pria yang bekerja, dimana wanita yang bekerja lebih sering mengalami beberapa gejala stres seperti sakit kepala, kegelisahan, depresi, gangguan tidur, dan gangguan makan dibandingkan dengan pria yang bekerja. ${ }^{14}$

Hasil studi pendahuluan pada tanggal 5 September 2019 di PT. Shoetown Majalengka Provinsi Jawa Barat terhadap 15 responden pekerja wanita dengan hasil 26,7\% responden mengalami stres berat dan $73,3 \%$ mengalami stres ringan, serta terdapat beberapa faktor yang diduga berhubungan dengan stres kerja yakni faktor organisasional seperti beban kerja, bila target produksi tidak tercapai mau tidak mau pekerja harus mengambil lembur tambahan.Faktor individual seperti kejenuhan kerja, tidak adanya rotasi pekerjaan rentan menimbulkan stres kerja karena pekerja mengalami kejenuhan dalam pekerjaannya.Faktor lingkungan seperti kondisi lingkungan kerja, tidak adanya pendingin ruangan (Air Conditioner) mengakibatkan suhu ruangan berubahubah sehingga dapat memicu terjadinya stres kerja.

\section{METODE PENELITIAN}

Penelitian ini merupakan penelitian kuantitatif dengan desain cross sectional. Variabel adalah perilaku atau karakteristik yang memberikan nilai beda terhadap sesuatu. ${ }^{15}$ Dalam penelitian ini yang menjadi variabel independen adalah faktor- faktor yang berhubungan dengan stres kerja (Beban Kerja, Kejenuhan Kerja dan Buruknya Kondisi Lingkungan Kerja), dan yang menjadi variabel dependen adalah stres kerja. Populasi dalam penelitian ini adalah wanita bekerja yang bekerja di PT Shoetown Majalengka periode bulan September 2019 sebanyak 1785 orang. Sampel adalah sebagian dari populasi yang nilai atau karakteristiknya diukur dan kemudian dipakai oleh peneliti untuk menduga karakteristik dari populasi. ${ }^{16}$ Teknik pengambilan sampel dalam penelitian ini menggunakan accidental sampling, yaitu semua pekerja wanita yang bekerja di PT. Shoetown Majalengka yang kebetulan bertemu dengan peneliti dijadikan sebagai responden. Pengumpulan data dalam penelitian ini menggunakan metode wawancara. Instrumen penelitian menggunakan kuesioner. Jenis dan sumber data yang digunakan dalam penelitian ini adalah berupa data primer dan data sekunder. Analisis bivariat ini menggunakan uji statistik chi square dengan tingkat kemaknaan 0,05 .

\section{HASIL PENELITIAN}

\section{Beban kerja kejenuhan kerja, dan lingkungan kerja wanita}

Tabel 1. Distribusi data responden berdasarkan faktor beban kerja, kejenuhan kerja, dan lingkungan kerja

\begin{tabular}{lcc}
\hline \multicolumn{1}{c}{ Kategori } & F (95) & Persentase (\%) \\
\hline Beban Kerja & & \\
\hline Ringan & 26 & 27,3 \\
Berat & 69 & \\
\hline Kejenuhan Kerja & & 10,5 \\
\hline Tidak Jenuh & 10 & 89,5 \\
Jenuh & 85 & \\
\hline Lingkungan Kerja & & 22,1 \\
Tidak Terganggu & 21 & 77,9 \\
Terganggu & 74 & \\
\hline
\end{tabular}


Pada tabel 1 menunjukkan bahwa dari 95 responden sebagian besar menyatakan beban kerja berat sebanyak 69 responden $(72,7 \%)$, sebagian besar menyatakan jenuh sebanyak 85 responden $(89,5 \%)$, dan sebagian besar responden menyatakan merasa terganggu sebanyak 74 responden $(77,9 \%)$.

\section{Kejadian stres kerja}

Tabel 2. Distribusi Data Responden Berdasarkan Kejadian Stres Kerja

\begin{tabular}{clc}
\hline Tingkat Stres & $\mathrm{n}$ & Persentase $(\%)$ \\
\hline Stres Ringan & 85 & 89,4 \\
Stres Berat & 10 & 10,6 \\
\hline Total & 95 & 100 \\
\hline
\end{tabular}

Pada tabel 2 menunjukkan bahwa dari 95 responden sebagian besar menyatakan stres ringan sebanyak 85 responden atau $89,4 \%$, yang menyatakan stres berat sebanyak 10 responden atau $10,6 \%$.

\section{Hubungan Beban Kerja Dengan Stres Kerja}

Tabel 3. Hubungan beban kerja dengan stres kerja

\begin{tabular}{llccccccc}
\hline \multirow{2}{*}{ No } & Beban Kerja & \multicolumn{4}{c}{ Stres Kerja } & \multicolumn{2}{c}{ Jumlah } & \multirow{2}{*}{ P Value } \\
\cline { 3 - 7 } & & \multicolumn{2}{c}{ Ringan } & \multicolumn{2}{c}{ Berat } & & \\
\cline { 3 - 8 } & & $\mathrm{N}$ & $\%$ & $\mathrm{n}$ & $\%$ & $\mathrm{~N}$ & $\%$ & \\
\hline 1 & Ringan & 26 & 100 & 0 & 0 & 26 & 100 & 0,040 \\
2 & Berat & 59 & 85,5 & 10 & 14,5 & 69 & 100 & \\
\hline & Jumlah & 85 & 89,5 & 10 & 10,5 & 95 & 100 & \\
\hline
\end{tabular}

Pada tabel 3 menunjukan bahwa responden yang memiliki penilaian beban kerja ringan sebanyak 26 orang semua terdistribusi pada kategori stres ringan. Sedangkan responden yang memiliki penilaian beban kerja berat sebanyak 69 orang terdistribusi lebih tinggi pada kategori stres ringan sebanyak 59 orang dan stres berat sebanyak 10 orang. Perbedaan proporsi ini menunjukkan perbedaan yang bermakna yang terlihat dari hasil uji chi square, yakni $p$ value $=0,040(<0,05)$ yang berarti hipotesis nol ditolak atau ada hubungan antara beban kerja terhadap kejadian stress kerja.

\section{Hubungan Kejenuhan Kerja Dengan Stres Kerja}

Tabel 4. Hubungan kejenuhan kerja dengan stres kerja

\begin{tabular}{llccccccc}
\hline \multirow{2}{*}{ No } & Kejenuhan Kerja & \multicolumn{4}{c}{ Stres Kerja } & & \multirow{2}{*}{ Jumlah } & \multirow{2}{*}{ P Value } \\
\cline { 3 - 7 } & & \multicolumn{2}{c}{ Ringan } & \multicolumn{2}{c}{ Berat } & & \\
\cline { 3 - 8 } & & $\mathrm{N}$ & $\%$ & $\mathrm{n}$ & $\%$ & $\mathrm{~N}$ & $\%$ & \\
\hline 1 & Tidak & 27 & 100 & 0 & 0 & 27 & 100 & 0,035 \\
2 & Ya & 58 & 85,3 & 10 & 14,7 & 68 & 100 & \\
\hline & Jumlah & 85 & 89,5 & 10 & 10,5 & 95 & 100 & \\
\hline
\end{tabular}

Pada tabel 4 menunjukan bahwa responden yang memiliki penilaian tidak merasa jenuh sebanyak 27 orang semua terdistribusi pada kategori stres ringan. Sedangkan responden yang memiliki penilaian merasa jenuh sebanyak 68 orang terdistribusi lebih tinggi pada kategori stres ringan sebanyak 58 orang dan stres berat sebanyak 10 orang. Perbedaan proporsi ini menunjukkan perbedaan yang bermakna yang terlihat dari hasil uji chi square, yakni $p$ value $=0,035(<0,05)$ yang berarti hipotesi nol ditolak atau ada hubungan antara kejenuhan kerja terhadap kejadian stres kerja. 


\section{Hubungan Lingkungan Kerja Dengan Stres Kerja}

Tabel 5. Hubungan lingkungan kerja dengan stres kerja

\begin{tabular}{|c|c|c|c|c|c|c|c|c|}
\hline \multirow[t]{3}{*}{ No } & \multirow{3}{*}{$\begin{array}{l}\text { Lingkungan } \\
\text { Kerja }\end{array}$} & \multicolumn{4}{|c|}{ Stres Kerja } & \multirow{2}{*}{\multicolumn{2}{|c|}{ Jumlah }} & \multirow[t]{3}{*}{$P$ Value } \\
\hline & & \multicolumn{2}{|c|}{ Ringan } & \multicolumn{2}{|c|}{ Berat } & & & \\
\hline & & $\mathrm{n}$ & $\%$ & $\mathrm{n}$ & $\%$ & $\mathrm{~N}$ & $\%$ & \\
\hline \multirow[t]{2}{*}{1} & Tidak & 25 & 100 & 0 & 0 & 25 & 100 & \multirow{4}{*}{0,046} \\
\hline & Mengganggu & & & & & & & \\
\hline \multirow[t]{2}{*}{2} & Mengganggu & 60 & 85,7 & 10 & 14,3 & 70 & 100 & \\
\hline & Jumlah & 85 & 89,5 & 10 & 10,5 & 95 & 100 & \\
\hline
\end{tabular}

Pada tabel 5 menunjukan bahwa responden yang memiliki penilaian lingkungan kerja tidak mengganggu sebanyak 25 orang semua terdistribusi pada kategori stres ringan. Sedangkan responden yang memiliki penilaian lingkungan kerja mengganggu sebanyak 70 orang terdistribusi lebih tinggi pada kategori stres ringan sebanyak 60 orang dan stres berat sebanyak 10 orang. Perbedaan proporsi ini menunjukkan perbedaan yang bermakna yang terlihat dari hasil uji chi square, yakni $p$ value $=0,046(<0,05)$ yang berarti hipotesis nol ditolak atau ada hubungan antara lingkungan kerja terhadap kejadian stres kerja

\section{PEMBAHASAN}

\section{Gambaran beban kerja, kejenuhan, dan lingkungan kerja pada pekerja wanita}

Timbulnya beban kerja berlebih adalah sebagai akibat dari tugas-tugas yang diberikan kepada tenaga kerja dan dirasakan oleh tenaga kerja sebagai beban kerja yang terlalu banyak untuk diselesaikan dalam waktu tertentu. ${ }^{5}$ Salah satu faktor penyebab stres kerja pada pekerja wanita di PT Shoetown Majalengka Tahun 2019 adalah beban kerja yang berlebih. Pekerjaan yang dilakukan secara terus menerus dalam jangka waktu cukup lama dapat membebani kerja tubuh. Pemberian jeda dalam rentang pekerjaan penting dilakukan untuk mengurangi beban kerja yang terlalu berlebih.Kurangnya perhatian terhadap hal tersebut mulai menimbulkan masalah stres kerja walaupun masih berupa stres ringan tapi bila tidak segera ditangani dapat menimbulkan masalah yg lebih serius.

Kejenuhan dalam bekerja merupakan manifestasi dari stres kerja yang menyebabkan produktivitas kerja menurun, adanya ketidakpuasan kerja, kurang motivasi, hilangnya gairah kerja (burnout), angka absen yang meningkat. ${ }^{19}$ Kejenuhan kerja cukup berpotensi untuk menyebabkan stres kerja.Pekerjaan yang monoton, tidak adanya rotasi pekerjaan menjadi alasan kenapa kejenuhan kerja itu terjadi dan memicu kepada stres kerja.Walaupun sebagian besar masih dalam tahap stres ringan tapi bila tidak segera ditangani dapat menimbulkan masalah yg lebih serius kedepannya bagi perusahaan.

Kondisi fisik lingkungan yang dapat mempengaruhi timbulnya stres kerja, diantaranya dapat berupa suhu yang telalu panas, terlalu dingin, terlalu sesak, kurang cahaya, lingkungan kerja kotor atau kebersihannya kurang, dan lain sebagainya. Ruangan yang terlalu panas (dapat berarti juga sirkulasi) menyebabkan ketidaknyamanan seseorang dalam menjalankan pekerjaannya, begitu juga ruangan yang terlalu dingin. ${ }^{20}$ Buruknya kondisi lingkungan dalam hasil penelitian ini diantaranya meliputi:

Kebersihan lingkungan kerja. Lingkungan kerja yang bersih dapat membuat perasaan menjadi tenang dan damai sehingga dapat dengan optimal dalam bekerja. Sebaliknya jika kondisi lingkungan buruk atau kotor akan menambah ketegangan dan mengganggu kinerja. ${ }^{21}$ Dalam hal ini sebagian responden merasa bahwa kondisi kebersihan lingkungan kerjanya kurang sehingga memicu timbulnya stres kerja. 
Pencahayaan dan sirkulasi udara. Pencahayaan dan sirkulasi udara yang cukup dan sesuai dibutuhkan pekerja untuk dapat melakukan pekerjaan dengan optimal. Dalam melaksanakan tugas sering kali karyawan membutuhkan penerangan yang cukup terutama bila pekerjaan yang dilakukan menuntut ketelitian, serta sirkulasi udara yang cukup dapat memberikan kesegaran fisik namun sebaliknya, pertukaran udara yang kurang akan menimbulkan kelelahan pada karyawan. ${ }^{21}$ Dalam hal ini sebagian responden merasa bahwa pencahayaan dan sirkulasi udara di tempat kerja kurang sehingga menimbulkan ketidaknyamanan dalam bekerja.

Kebisingan dapat mengganggu konsentrasi. Dengan adanya kebisingan maka akan mengganggu konsentrasi karyawan, sehingga akan menimbulkan kesalahan atau kerusakan. ${ }^{21}$ Dalam penelitian ini sebagian responden merasa terganggu dengan kebisingan yang ada di tempat kerja maupun di sekitarnya, sehingga menimbulkan kelelahan dan mengganggu konsentrasi kerja yang pada akhirnya berpotensi mengalami stres kerja.

\section{Gambaran stres pada pekerja wanita}

Seseorang baik pria maupun wanita perlu bekerja untuk dapat memenuhi kebutuhan dan memperoleh apa yang diinginkannya. Dalam bekerja tidak menutup kemungkinan akan terjadi ketegangan pada diri pekerja di tempat kerja maupun di luar tempat kerja. Stres kerja dalam penelitian ini diukur dengan menggunakan beberapa pertanyaan yang mengindikasikan pada stres kerja meliputi perubahan fisiologis, psikologis, dan perilaku.

Selain faktor penyebab stres kerja dari dunia kerja, juga terdapat penyebab stres dari luar pekerjaan seperti metabolisme biologis dari wanita itu sendiri diantaranya wanita mengalami dysminorrhae. Dysminorrhae merupakan salah satu faktor penyebab stres kerja lebih tinggi dari pria bekerja karena wanita bekerja merasa tanggung jawab pekerjaannya terganggu akibat gangguan menstruasi tersebut. Sedangkan dalam hasil penelitian ini sebagian besar responden tidak mengalami gangguan menstruasi baik dysminorrhae, terlambat datang bulan, maupun gangguan menstruasi lainnya. ${ }^{4}$

Hasil penelitian ini menunjukkan bahwa sebagian besar responden mengalami stres kerja ringan yakni sebesar $89,5 \%$ dan mengalami stres berat $10,5 \%$. Hal tersebut kemungkinan dapat disebabkan oleh berkurangnya permasalahan yang dialami wanita bekerja dalam dunia kerja dan lingkungan luar kerja.

Penelitian lainnya mengenai stres kerja juga diperoleh presentase stres kerja ringan yang lebih besar, diantaranya yakni hasil penelitian dari Airmayanti yang menyatakan bahwa sebesar $55,6 \%$ atau sebagian besar karyawan yang mengalami stres kerja ringan lebih banyak dibandingkan karyawan yang mengalami stres kerja berat. ${ }^{11}$

Meskipun sebagian besar responden dalam penelitian ini mengalami stres kerja ringan, namun jika hal tersebut tidak ditangani secara dini maka akan dapat berkembang secara kronik dan menjadi lebih serius. Akibatnya pekerja mengalami penyimpangan perilaku dan fungsi yang normal yang pada akhirnya dapat mengganggu kinerjanya ${ }^{18}$

Pencegahan stres ringan agar tidak menjadi lebih serius ini dapat dilakukan sendiri oleh pekerja maupun dari perusahaan tempat kerjanya. Perusahaan dapat melakukan beberapa upaya pencegahan stres kerja diantaranya:

1) Adanya peraturan tentang identifikasi bahaya kerja termasuk identifikasi terhadap bahaya psikososial kerja. Stres merupakan kondisi ketidakseimbangan psikososial yang dapat diketahui dari beberapa gejala yang tampak. Dengan adanya identifikasi bahaya tersebut diharapkan stres dapat ditanggulangi secara dini.

2) Memberi kesempatan kepada pekerja untuk mengembangkan keterampilannya termasuk keleluasaan dalam memberikan pendapat tentang organisasi tempat kerja. Dengan adanya keleluasaan tersebut perusahaan dapat mengetahui hal-hal yang dapat menyebabkan pekerja merasa menjadi stres akan kondisi kerja, sehingga perusahaan dapat melakukan upaya pencegahan dan penanggulangan segera. 


\section{Hubungan Beban Kerja dengan Kejadian Stres Kerja}

Hasil uji statistik diperoleh $p$ value $=0,040(<0,05)$ yang berarti hipotesis nol ditolak atau ada hubungan antara Beban Kerja terhadap kejadian stress kerja di PT. Shoetown Majalengka, Kabupaten Majalengka Tahun 2019. Hasil penelitian ini sejalan dengan Nugrahani yang juga menyebutkan bahwa terdapat hubungan antara beban kerja dengan tingkat stres kerja, dimana semakin pekerja merasa beban kerjanya berlebih maka tingkat stres yang dialami semakin berat, dan sebaliknya. ${ }^{10}$ Penelitian dengan hasil serupa juga diungkapkan oleh Airmayanti yakni ada hubungan antara beban kerja dengan stres kerja atau dapat dikatakan bahwa beban kerja merupakan faktor pencetus stres kerja. ${ }^{11}$

Timbulnya beban kerja berlebih atau terlalu sedikit adalah sebagai akibat dari tugas-tugas yang diberikan kepada tenaga kerja dan dirasakan oleh tenaga kerja sebagai beban kerja yang terlalu banyak atau sedikit untuk diselesaikan dalam waktu tertentu. Beban kerja berlebih atau terlalu sedikit timbul jika orang merasa tidak mampu untuk melakukan suatu tugas, atau suatu tugas tidak menggunakan keterampilan dan/atau potensi dari tenaga kerja. Banyaknya tugas akan menjadi sumber stres apabila tidak sebanding dengan kemampuan baik fisik maupun keahlian dan waktu yang tersedia bagi pekerja tersebut. ${ }^{5}$

Hasil penelitian ini menggambarkan bahwa faktor beban kerja memiliki pengaruh terhadap kejadian stres kerja. Hal ini dikarenakan beban kerja yang tinggi memaksa tubuh pekerja untuk bekerja lebih berat dan mengganggu kondisi kesehatan kemudian menimbulkan stres kerja.

\section{Hubungan Kejenuhan Kerja dengan Kejadian Stres Kerja}

Hasil penelitian menemukan bahwa dari 95 responden merasa tidak jenuh sebanyak 27 responden atau 28,4\%, yang menyatakan jenuh sebanyak 68 responden atau 71,6\% yang terdistribusi 85 orang stress ringan dan 10 orang mengalami stres berat.

Hasil uji statistik diperoleh $p$ value $=0,035(<0,05)$ yang berarti hipotesis nol ditolak atau ada hubungan antara kejenuhan kerja terhadap kejadian stres kerja. Hal ini sejalan dengan penelitian Nugrahani yang menyebutkan rasa jenuh umumnya timbul karena kondisi kerja yang monoton sepanjang waktu dan apabila tidak ada perubahan ataupun tidak ada stimulus yang baru akan membuat pekerja menjadi stres. Dalam hal ini, pekerjaan rutin yang berulang-ulang secara umum dialami sebagai suatu hal yang membosankan dan monoton sehingga pekerja merasa jenuh, dan hal ini dapat menimbulkan stres. ${ }^{10}$

Kejenuhan dalam bekerja salah satunya timbul karena pekerja merasa bosan dengan pekerjaan yang selalu sama atau berulang setiap tahunnya. Kejenuhan kerja tersebut dapat ditandai dengan pembolosan, keterlambatan, perubahan kerja yang banyak, perdebatan, dan kekerasan fisik. ${ }^{19}$

Gejala khusus dari kejenuhan kerja ini berupa kebosanan, depresi, pesimisme, kurang konsentrasi, kualitas kerja buruk, ketidakpuasan, absen, dan kesakitan atau sakit. Kejenuhan kerja cukup berpotensi untuk menyebabkan keletihan kerja sehingga pekerja merasa bahwa dirinya hanya memiliki sedikit kontrol terhadap faktor-faktor di tempat kerja atau bahkan tidak memiliki kontrol sama sekali. Dari gambaran inilah mengapa kejenuhan kerja dapat menjadi faktor pencetus stres kerja. $^{8}$

Kebosanan dalam bekerja merupakan perwujudan dari stres kerja yang menyebabkan produktivitas kerja menurun, adanya ketidakpuasan terhadap pekerjaan, kurangnya motivasi. Hasil penelitian ini menggambarkan bahwa faktor kejenuhan kerja memiliki pengaruh terhadap kejadian stres kerja. Asumsi peneliti hal ini dikarenakan tingginya kejenuhan kerja yang dirasakan memicu tingkat stress yang lebih tinggi sehingga mempengaruhi terhadap kinerja pekerja.

\section{Hubungan Buruknya Lingkungan Kerja dengan Kejadian Stres Kerja}

Hasil penelitian menemukan bahwa dari 95 responden yang tidak merasa terganggu sebanyak 25 responden atau 26,3\%, yang menyatakan terganggu sebanyak 70 responden atau $73,7 \%$ yang terdistribusi 85 orang stres ringan dan 10 orang mengalami stres berat. Hasil uji 
statistik diperoleh $p$ value $=0,046(<0,05)$ yang berarti hipotesis nol ditolak atau ada hubungan antara lingkungan kerja terhadap kejadian stres kerja

Hasil ini sesuai dengan teori faktor stres kerja oleh National Safety Council. Hasil penelitian ini juga sejalan dengan Nugrahani yang menyatakan bahwa terdapat hubungan antara buruknya lingkungan kerja dengan stres kerja pada pekerja. ${ }^{10}$

Kondisi lingkungan fisik dapat berupa suhu yang telalu panas, terlalu dingin, terlalu sesak, kurang cahaya, lingkungan kerja kotor atau kebersihannya kurang, dan lain sebagainya. Ruangan yang terlalu panas (dapat berarti juga sirkulasi) menyebabkan ketidaknyamanan seseorang dalam menjalankan pekerjaannya, begitu juga ruangan yang terlalu dingin. Di samping itu, kebisingan juga memberikan pengaruh yang cukup besar terhadap munculnya stres kerja karena beberapa orang lebih sensitif pada kebisingan dibanding yang lain. ${ }^{20}$

Hasil penelitian ini menggambarkan bahwa faktor lingkungan kerja memiliki pengaruh terhadap kejadian stres kerja. Hal ini dikarenakan suhu ruangan yang tidak stabil, sirkulasi udara yang kurang baik, kebersihan yang kurang terjaga, dan kebisingan di tempat kerja memicu tingkat stres yang lebih tinggi sehingga mempengaruhi terhadap kesehatan pekerja.

\section{SIMPULAN}

1. Berdasarkan faktor beban kerja dari 95 responden yang menyatakan merasa beban kerja terasa berat sebanyak 69 responden.

2. Berdasarkan faktor kejenuhan kerja dari 95 responden yang menyatakan jenuh sebanyak 68 responden.

3. Berdasarkan faktor lingkungan kerja dari 95 responden yang menyatakan terganggu sebanyak 70 responden.

4. Hasil penelitian menunjukkan bahwa sebagian responden mengalami stres kerja ringan yakni sebesar $89,5 \%$ dan mengalami stres kerja berat $10,5 \%$.

5. Ada hubungan antara beban kerja dengan stres kerja pada pekerja wanita di PT. Shoetown (p value 0,040).

6. Ada hubungan antara kejenuhan kerja dengan stres kerja pada pekerja wanita di PT. Shoetown (p value 0,035).

7. Ada hubungan antara buruknya kondisi lingkungan kerja dengan stres kerja pada pekerja wanita di PT. Shoetown (p value 0,046).

\section{SARAN}

1. Bagi STIKes Cirebon

Diharapkan dalam metode pembelajaran di institusi pendidikan dapat lebih memperdalam pembahasan tentang faktor-faktor penyebab terjadinya stres kerjasehingga lulusannya dapat memberikan pelayanan kesehatan yang berkualitas dan maksimal.

2. Bagi Peneliti Lain

Diharapkan peneliti selanjutnya selain dapat menganalisis lebih lanjut, peneliti selanjutnya juga diharapkan dapat menambahkan variabel lainnya dan tidak hanya terbatas pada variabel-variabel dalam penelitian ini saja.

3. Bagi Responden

Diharapkan pekerja memahami apa yang menjadi faktor-faktor penyebab stres kerja dan berupaya meningkatkan pengetahuan dan keterampilan berikaitan dengan pekerjaannya.

4. Bagi Perusahaan

Diharapkan perusahaan melakukan upaya perbaikan untuk mengatasi faktor-faktor penyebab stres kerja yang terjadisehingga pekerja dapat lebih optimal dalam bekerja. 


\section{DAFTAR PUSTAKA}

1. S Alma. Pekerjaan adalah penyebab utama stres. Artikel Majalah Kesehatan [Online] 2013. [Diakses tanggal 2 September 2019]. Tersedia dari http://majalahkesehatan.com/pekerjaanadalah-penyebab-utama-stres/.

2. Vierdelina N. Gambaran stres kerja dan faktor-faktor yang berhubungan pada pengemudi Bus Patas 9B Jurusan Bekasi Barat-Cililitan/Kampung Rambutan Jakarta: FKM. Universitas Indonesia; 2008.

3. Leka S., et al. Work organization \& stres, Protecting Worker"s Helath Series No. 3 Zwitzerland: World HealthOrganization.; 2003.

4. Rini, J. F. 2002. Wanita bekerja. Jakarta [diakses tanggal 2 September 2019]. Tersedia dari http://www.e- psikologi.com/epsi/search.asp

5. Munandar, A. S. Psikologi industri dan organisasi. Jakarta: UI-Press; 2008.

6. Greenberg, J. S. Comprehensive stres management (eighth ed.). New York: McGraw-Hill Companies Inc. 2002.

7. Robbins, P. S. Organizational behaviour concepts, controversies, application. New Jersey: Prentice-Hall International, Inc. 1998.

8. National Safety Council. Stres management, Yulianti, Devi (Editor). Manajemen stres. Jakarta: EGC. 2004.

9. Saragih, Harlen. Pengaruh karakteristik organisasi dan individu terhadap stres kerja Perawat di ruang rawat inap Rumah Sakit Umum Daerah Porsea. [Tesis]. Kota tempat terbit: S2 Sekolah Pascasarjana Universitas Sumatera Utara;2008.

10. Nugrahani, Salafi. Faktor-faktor yang berhubungan dengan stres kerja pada pekerja bagian operasional PT Gunze Indonesia Tahun 2008. [Skripsi]. Depok: S1 Fakultas Kesehatan Masyarakat. Universitas Indonesia; 2008.

11. Airmayanti, Diah. Faktor-faktor yang mempengaruhi stres kerja pada pekerja bagian produksi PT ISM Bogasari Flour Mills Tbk Tanjung Priok Jakarta Utara Tahun 2009. [Skripsi]. Jakarta: S1 Fakultas Kedokteran dan Ilmu Kesehatan. UIN Syarif Hidayatullah Jakarta;2010.

12. Badan Pusat Statistik. Profil wanita Indonesia 2011. Jakarta: Kementerian Pemberdayaan Wanita dan Perlindungan Anak RI;2011.

13. Setiawan Z.Y. Stres kerja dan kecenderungan gejala gangguan mental emosional pada Pekerja Redaksi Harian PT. PMM Jakarta. [Tesis]. Jakarta: Universitas Indonesia; 2006.

14. Schultz, Duane dan Ellen, S. Schultz. Psychology \& work today (Ninth Ed.). Canada: Pearson prentice hall. 2006.

15. Nursalam. Konsep dan penerapan metodologi penelitian ilmu keperawatan, pedoman skripsi, tesis dan instrumen penelitian keperawatan. Jakarta: Salemba Medika;2003.

16. Sabri, Luknis dan Hastono, S. P. Statistik kesehatan. Jakarta: PT Rajagrafindo Persada;2006.

17. Notoatmodjo. Metodologi penelitian kesehatan. Jakarta: Rineka Cipta;2005.

18. Inayani, Yani. Analisis perbedaan faktor demografi dalam strategi penanggulangan stres kerja: studi kasus Dinas Kesehatan Kota Bogor. [Tesis].Bogor: S2 Sekolah PascaInstitut Pertanian Bogor;2011.

19. Rahmawati, Anida. Hubungan antara karakteristik pekerjaan dan sikap terhadap lingkungan kerja dengan kebosanan kerja. [Skripsi]. Surakarta: S1 Fakultas Psikologi Universitas Muhammadiyah Surakarta;2007.

20. Irawan R. A. Analisis pengaruh stres kerja dan gaya kepemimpinan terhadap kinerja karyawan pada P.D BPR Jepara Artha. [Skripsi].Semarang:S1 Fakultas Ekonomi Universitas Diponegoro; 2010.

21. Aribowo, $R$. N. Pengaruh kepemimpinan, motivasi, dan lingkungan kerja fisik terhadap kinerja karyawan (Studi pada CV Karya Mina Putra Rembang Devisi Kayu). [Skripsi]. Semarang: SI Fakultas Ekonomi Universitas Diponegoro:2011. 